\title{
腹腔鏡下手術で確認された傍卵巣囊腫茎捻転、多囊胞性卵巣
} 及び卵巣線維腫を伴った広沉性卵巣浮腫の一症例

\section{A case of massive ovarian edema with paraovarian cyst torsion, poly cystic ovary and ovarian fibroma on laparoscopic surgery}

耳原総合病院 產婦人科 坂本能基、中西俊一郎、内田学

\section{緒言}

広沉性卵巣浮腫massive ovarian edemaは、若 年者に多く茥捻転など緊急時に遭遇することが多 い疾患である11。緊急時は患性疾患との除外診断 を十分に行えない状況下で手術を行うことになり、 広汎性卵巣浮腫の臨床的特徵を周知することは無 用な卵巢摘出を回避するなど臨床判断上で重要と 思われる。今回、緊急手術時に広汎性卯巣浮腫を 疑い、卵巣を温存できた症例を経験した。広沉性 卵巣浮腫と卵巢茎捻転の文献的考察を含め報告す る。

\section{症例}

【主訴】右下腹部痛

【家族歴、既往歷】特記事項は無し

【月経歴】初経は11才であったが月経不順が続き 14 才頃から無月経となった。

【妊娠歴】未経妊未経産

【現病歴】症例は、17才の女性。2 日前より腹部 全体の痛みを自覚していたが、当日の早朝より強 い右下腹部痛を自営した為、近くの診療所を受診 し、急性虫垂炎の疑いで当院外科に紹介となった。 腹部超音波検查で卵巣囊腫の茎捻転が疑われ当科 に紹介となった。

【診察所見】存下腹部に压痛、筋性防御を認めた が、反跳痛はなかった。

【血液所見】CRP $0.5 \mathrm{mg} / \mathrm{dl}$ WBC 8800

【腹部単純写真】異常を認めなかった。

【経腟超音波検查】右附属器付近に $7.4 \times 4.3 \times 5.7 \mathrm{~cm}$ のネックレスサインを有する充実性腫韵像と左附 属器付近に $5.8 \times 4.4 \times 3.9 \mathrm{~cm}$ の単純性囊腫像を認め た（図 $1 \mathrm{~A} 、 \mathrm{~B}$ )。充実性腫瘍像は右側でネック
レスサインを有すること、症例は 17 才、無月経で あることなどの特徵から広沉性卵巣浮腫が強く疑 われた。

図 1 経朦超音波検査 $A$ 、水平断面 $B$ 、矢状断面 右卵巣の腫大と考えられる $7.4 \times 4.3 \times 5.7 \mathrm{~cm}$ のネックレスサイ ンを有する充実性腫貆像と左附属器付近の $5.8 \times 4.4 \times 3.9 \mathrm{~cm}$ 大 の単純性裔腫像
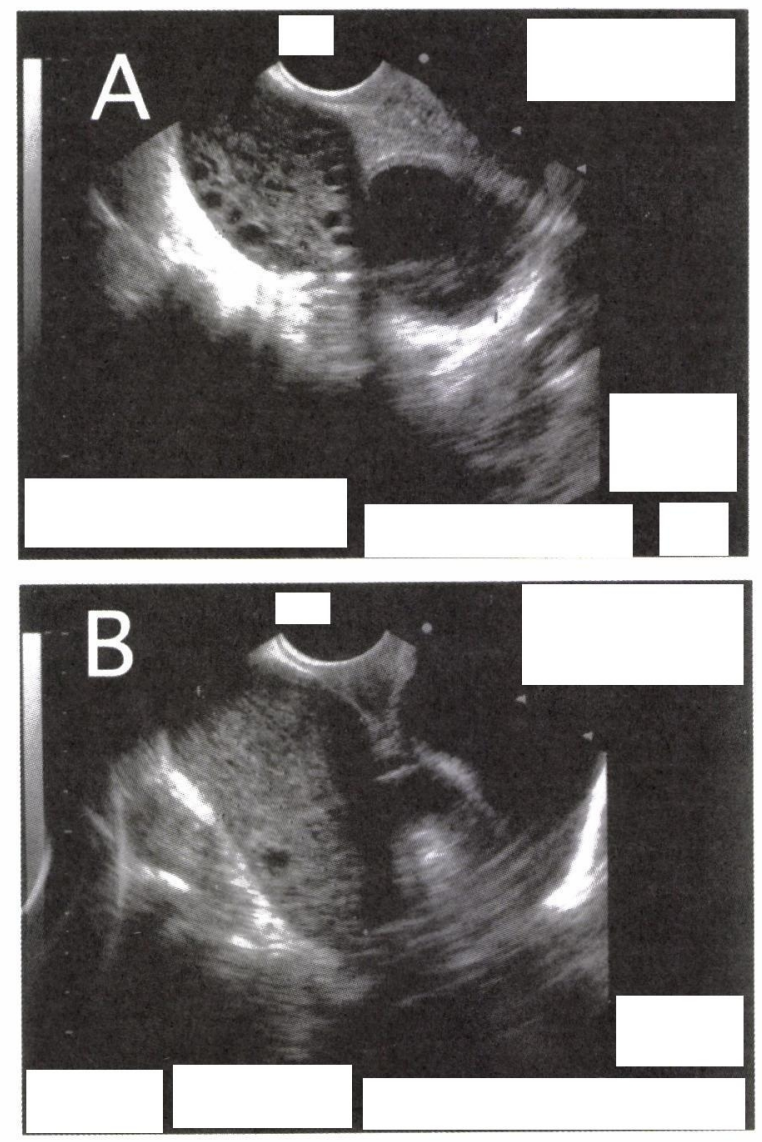

【骨盤 C T】在附属器付近に充実性腫瘍像と子宮 体部を含吉断面で左附属付近に囊胞性腫湯像と子 宮頝部を含む断面で左卵巣と考えられる $3 \mathrm{~cm}$ 大の 
図 2 CT検査

A、子宮体部の高さの断面：右附属器の充実性腫瘍像と左附属 付近の囊胞性腫瘍像

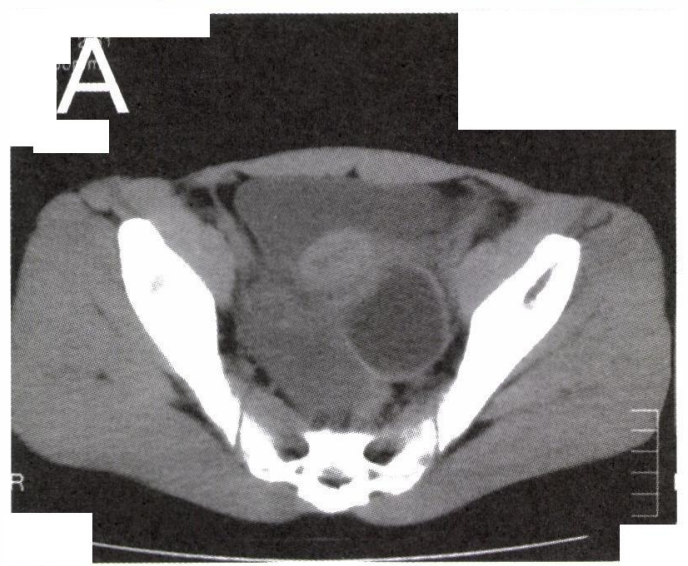

B、子宮頝部の高さの断面：右附属器の充実性腫瘍像と左附属 器と考えられる $3 \mathrm{~cm}$ 大の陰影

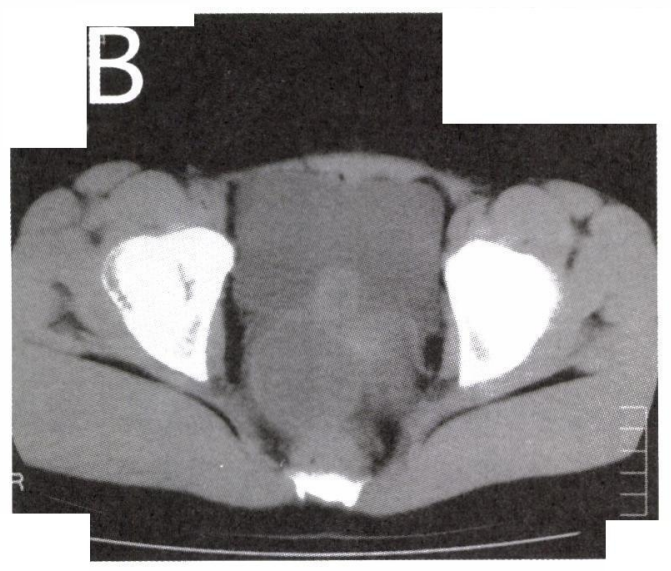

腫瘤像を確認できた（図 2 A、B)。左右の卵巣 が存在する可能性があり、囊腫は傍卵巣囊腫であ る可能性も考えられた。

【術前診断】腹痛の原因は、囊腫もしくは充実性 腫瘍の捻転と診断した。発症から12時間経過して おり卵巣を摘出する可能性があることを本人およ び家族に説明した。さらに充実性腫瘍は悪性の可 能性もあることを説明し、肉眼的に悪性が強く疑 われたときはトロカー挿入部位の再発を考慮し、 開腹術に移行した上で卵巣を摘出することの了解 を得て緊急腹腔鏡下手術を決定した。

【手術所見】全身麻酔のもとに臍部、臍左側と左 下腹部に径 $5 \mathrm{~mm}$ のトロカーを装着し、さらに右 下腹部に $12 \mathrm{~mm}$ ラパロザックトロカーを装着した。 腹腔内を観察するに、右附属器に暗赤色に変色 した黛卵大の腫瘤を認め、右傍卵巣囊腫が卵管膨 大部で時計方向に360度捻転を起こしており、腹痛 の原因と考えられた（四 $3 \mathrm{~A}$ )。術前の画像診断 で左側にあった囊腫は、右側の傍卵巣囊腫であっ た。右傍卵巣囊腫と腫大した卵管膨大部の捻転部
図 3 腹腔鏡下手術所見

A、捻転し暗赤色に腫大した右傍卵巣襄腫

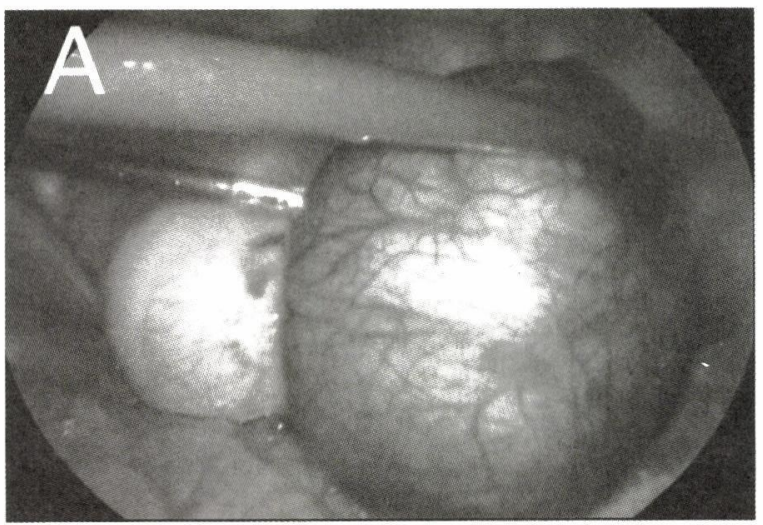

位を摘出し、回収袋にて体外に誘導した。

右卵巣は捻転を起こしていなかったが、黛卵大 に腫大し乳白色、表面平滑であり周囲との癒着は なく、㕕汎性卵巣浮腫、卵巣線維腫などの良性腫 瘍と判断した（図 $3 \mathrm{~B}$ )。特に、超音波所見でネ ックレスサインを有する充実性腫痬像であること、 卵巣周囲に傍卵巣囊腫や硬腫瘤を伴うこと、17才

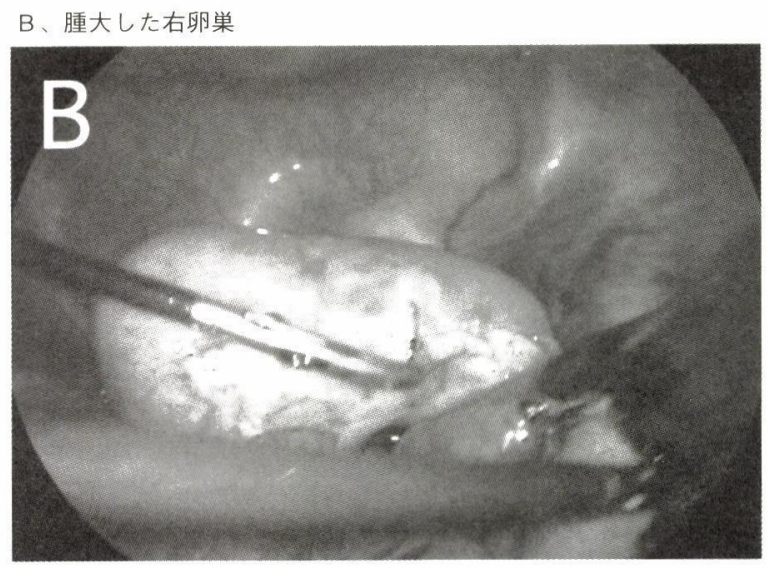

で無月経であることなどの特徴から広汎性卵巣浮 腫を強く疑った。卵巣壁を部分切除し病理に提出 した (図 3 C) 。迅速病理検査は、時間帯の問題 で施行できなかった。体内法で卵巣にZ縫合を行

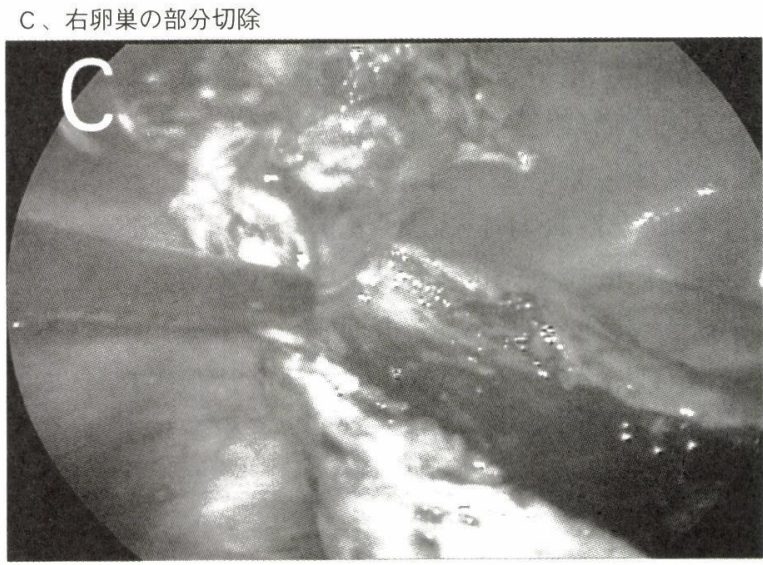


D、右卵管間膜の線維腫

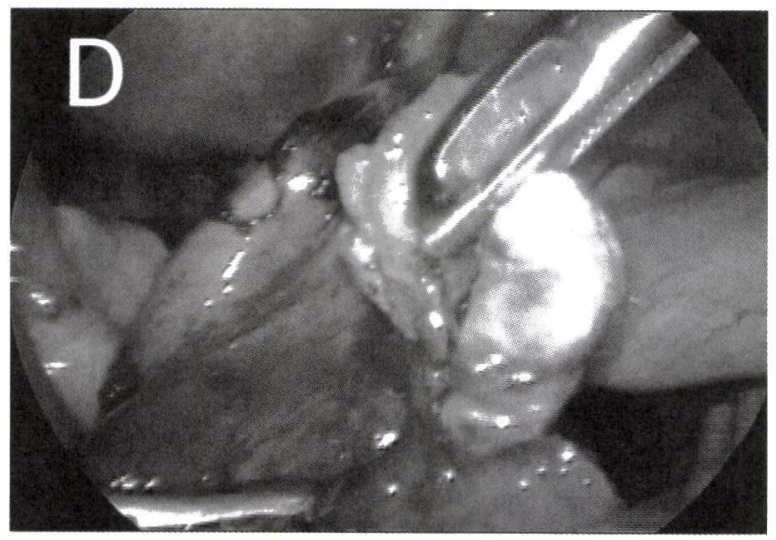

つた。右卵管間膜に直径 $1 \mathrm{~cm}$ 頭大の硬腫瘤を認め 切除した (図 3 D)。

左卵巣は正常大であったが、直径 $2 \mathrm{~cm}$ 大の有茎 性の硬腫瘤を有し、卵巣線維腫などの良性腫瘍と 判断し切除した（図 $3 \mathrm{E}$ )。左卵管間膜に直径 2 cm頭大の硬腫瘤を認め切除した。また、ダグラス 窩に血性腹水を少量認め、これを採取し細胞診に 提出した。

\section{$\mathrm{E}$ 、左正常卵巣と有茎性腫瘍}

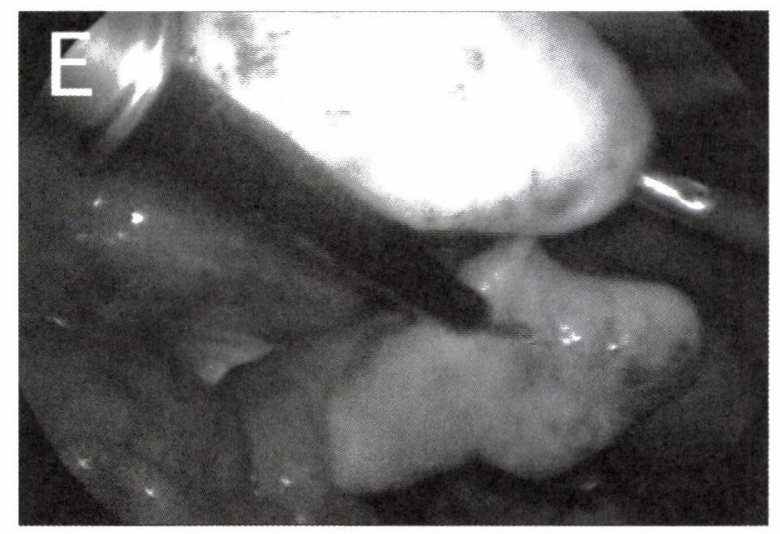

【病理診断】摘出標本（网 $4 \mathrm{~A} 、 \mathrm{~B}$ ) において、 右卵巣は卵巣髄質、皮質の間質に高度の浮腫があ り最外層で卵巣の構造が保たれていることから広 汎性卵巣浮腫（図 5 A、B、C）と診断した。傍 卵巣囊腫は漿液性腺腫であり、卵巣および卵管間 膜の硬腫瘤は線維腫（図 5 D ）であった。腹水細 胞診は悪性細胞陰性であった。

【手術直後】TSH $1.63 \mathrm{uIU} / \mathrm{ml}$ 、FreeT3 $2.58 \mathrm{pg} / \mathrm{ml}$ 、 FreeT4 1.30ng/ml、テストステロン $34 \mathrm{ng} / \mathrm{dl}$ 、エ ストラジオール $35 \mathrm{pg} / \mathrm{ml} 、 \mathrm{LH} 6.2 \mathrm{mIU} / \mathrm{ml} 、 \mathrm{FSH}$ $6.30 \mathrm{mIU} / \mathrm{ml}$ であり、卵巣および甲状腺の機能異常 を認めなかった。また、ゲスターゲンテスト陽性 で第I度無月経と診断した。
図 4 摘出標本

A、右側附属器：傍卵巣囊腫と卵管膨大部、右卵巣部分切除

(左下)、卵管間膜の線維腫（右下）

$B$ 、左附属器: 有茎性の卵巣線維腫
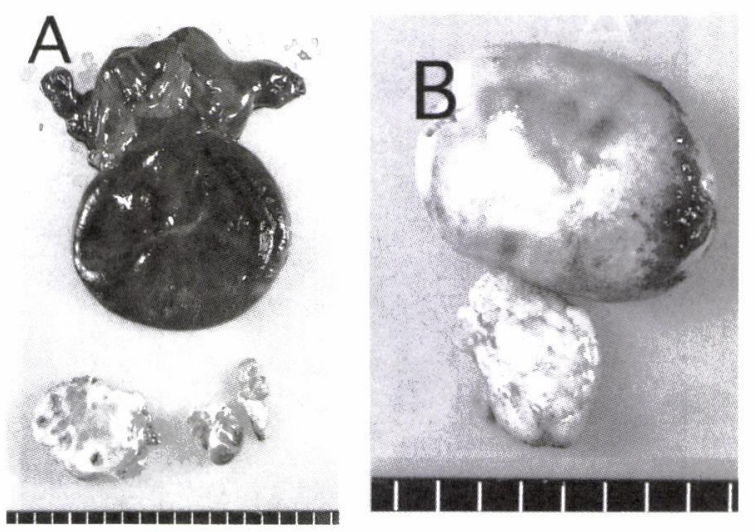

図 5 病理標本

A、右卵巣 : 広汎性卵巣浮腫 卵巣の正常外層と間質の浮腫性 変化

B、右卵巣 : 広汎性卵巣浮腫 卵巣の正常外層

C、右卵巣：広汎性卵巣浮腫 卵巣の間質の浮腫性変化

D、卵巣線維腫
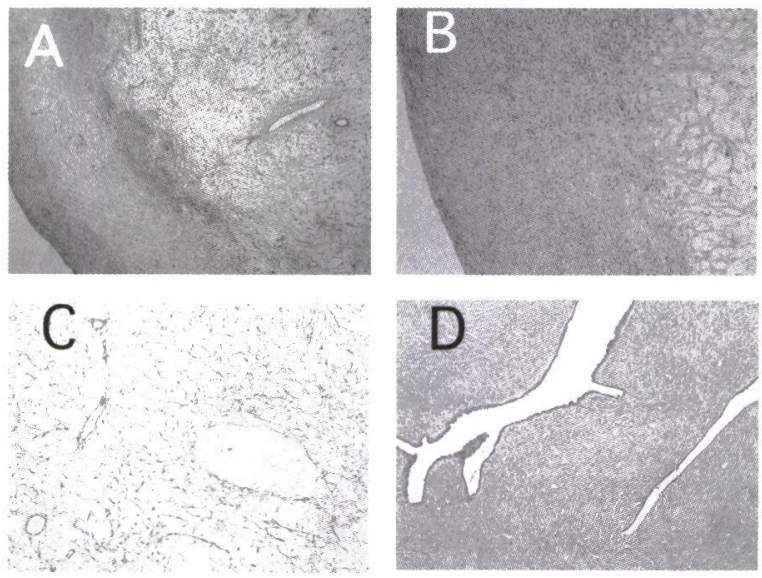

【手術後 6 ケ月】経胵超音波検査で右卵巣は $4.22 \times 2.72 \mathrm{~cm}$ とやや腫大し多囊胞性卵巣を呈してい たが、術前と比較して著明に縮小し広沉性浮腫は 改善していた（図 6 A)。左卵巣2.98x2.13cmは正 常大であったが、多囊胞性卵巣様であった（図 6 B)。TSH $0.75 \mathrm{uIU} / \mathrm{ml}$ 、FreeT3 $2.41 \mathrm{pg} / \mathrm{ml}$ 、 FreeT4 $0.94 \mathrm{ng} / \mathrm{ml}$ 、テストステロン $52 \mathrm{ng} / \mathrm{dl}$ 、エ ストラジオール $43 \mathrm{pg} / \mathrm{ml} 、 \mathrm{LH} 4.4 \mathrm{mIU} / \mathrm{ml} 、 \mathrm{FSH}$ $4.90 \mathrm{mIU} / \mathrm{ml}$ でり、卵巣および甲状腺の機能異常 を認めなかった。

【手術後 1 年】経腟超音波検査では右卵巣 $3.95 \times 2.57 \mathrm{~cm}$ (図 $6 \mathrm{C}$ )、左卵巣 $2.78 \times 1.42 \mathrm{~cm}$ (図 $6 \mathrm{D})$ であり6 月月目と同じ所見であった。手術 後も無月経が続いていた。多囊胞性卵巣を呈する も内分泌学的所見は正常であり、多囊胞性卵巣症 候群の診断基準 ${ }^{2)}$ を満たさなかった。 
図 6 経腟超音波検査
A 、術後 6 ケ月目の右卵单 $4.22 \times 2.72 \mathrm{~cm}$
B、術後 6 ヶ月目の左卵巣 $2.98 \times 2.13 \mathrm{~cm}$
C、術後 1 年目の右卵单 $3.95 \times 2.57 \mathrm{~cm}$
$D$ 、術後 1 年目の左卵巣 $2.78 \times 1.42 \mathrm{~cm}$
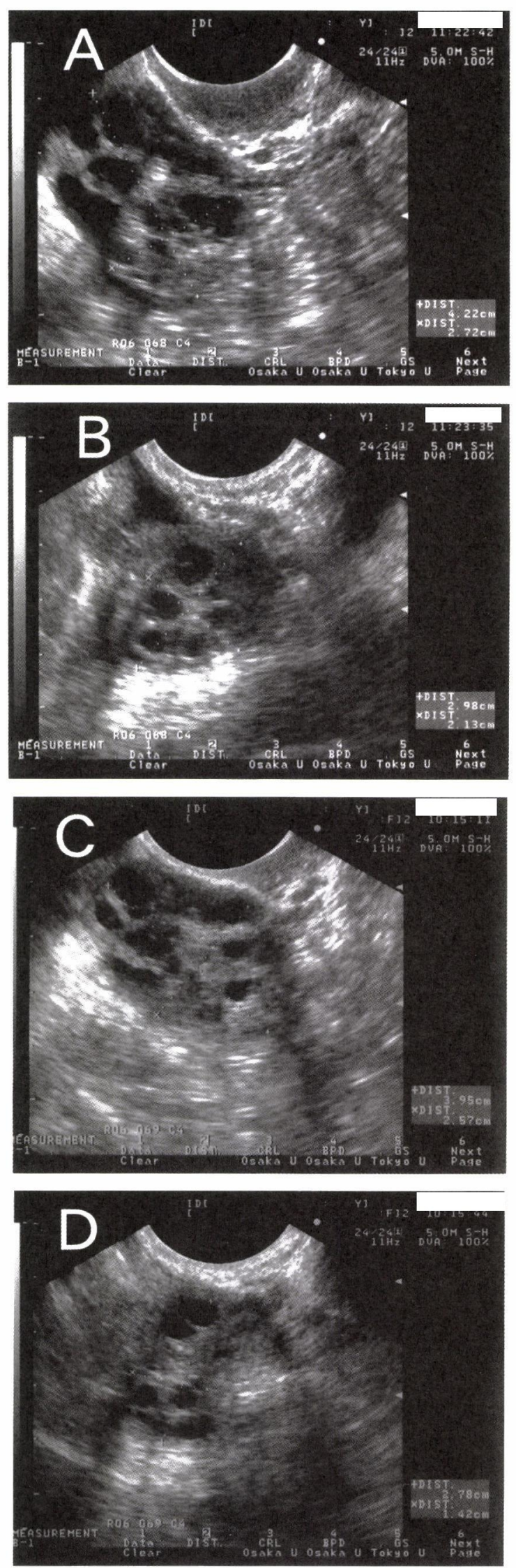

\section{考察}

緊急時に悪性疾患の除外診断を十分に行えない 状況下で、臨床的特徽から広沉性卵巣浮腫を疑い、 卵巣を温存できた症例を経験した。卵巣広沉性浮 腫について臨床的特徵を周知することは重要なこ とであると考える。

卵巣広汎性浮腫は、「卵巣間質に浮腫変化をき たし、腫大する良性の卵巣腫大」と定義され、 Kalstoneらが1969年に報告 ${ }^{3)}$ して以来、文献が散 見されていたが、最近、急速に症例の報告が増加 しており、茎捻転を起こしうる対象として熟知し ていなけ扎ばならない。永野らは、年齢は 6 才か ら58才とばらつきがあるが、平均18才と比較的若 年者に多く見られ、約 $45 \%$ に捻転を伴っていると 報告している11。また、Bychkovら ${ }^{4)}$ は、約70\% に月経異常、約 $10 \%$ に男性化を伴っていると報告 している。本症例も17才、無月経と臨床的特徴を 有していた。組織学的には卵巣髄質、皮質の間質 の高度浮腫が特徴で、最外層で卵巣の構造が保た れていることが多い5)。MRIの所見においてT1強 調画像では高信号、T2強調画像では低信号でネッ クレス状の複数の小囊胞を有する腫大した卵巣を 特徵とする ${ }^{6)}$ 。本症例では時間の制約上でMRIを 施行できなかったが、施行していれば経腟超音波 検査の所見（ネックレスサインを有する充実性腫 瘍像）と合わせて術前に広汎性卵巣浮腫の疑いを 強めることができたと思われる。

発生機序は不明とされているが、1，還流障害 説、2. 器質説が考えられている ${ }^{4)}$ 。還流障害説 は、部分的・間欠的な捻転により卵巣の静脈還流 が間久的に遮断されることで間質の浮腫が起きる。 器質説は、間質のfibromatosis や hyperthecosis または多囊胞性卵巣 ${ }^{7)}$ などが生じて、腫大した卵 巣が二次的に茥捻転を起こし広沉性浮腫を生じる。 本症例では、卵巣周囲に傍卵巣囊腫や卵巣線維腫 が存在したことから還流障害説で説明できる。ま た、術後に多囊胞性卵巣を呈していることから器 質説でも説明できる状態が関与していた可能性も ある。卵巣広範性浮腫は、還流障害の改善や捻転 の解除により浮腫が改善する可能性があり、早期 の腹腔鏡下による診断又は捻転解除により卵巣の 温存を考虑すべき対象となる。本症例では傍卵巣 囊腫と卵巣線維腫の摘出により還流障害が改善し、 広沉性卵巣浮腫が消失したと考えられる。しかし、 多囊胞性卵巣は継続しており再び広汎性卵巣浮腫 を起こす可能性は残っている。 
西田らは卵巣茎捻転の発症後36時間で病理学的 にも正常組織の証明が難しくなると報告している8 また、発症から 6 日経過後に手術で捻転を解除し、 術後 1 ケ月後では超音波所見で卵巣は腫大し、カ ラードップラーでも卵巣の血流を認めなかったが、 術後 5 ケ月後の超音波所見で卵巣は正常大に変化 し、カラードップラーでも卵巣の血流を認めるよ うになったという報告もある゙)。さらに、卵巣を 温存した場合と切除した場合との比較で合併症に 差は見られず、約 $75 \%$ は正常卵巣機能に復帰し、 卵巣温存は安全な処置方法であるとする報告もあ る $^{10)}$ 。これらの報告から早期の腹腔鏡下手術によ る捻転解除により卵巣を温存するように努めるこ とが肝要であると考える。本症例においても結果 的に卵巣捻転はなかったが、発症後12時間経過し ているものの若年者であることから卵巣温存の可 能性を考えながら緊急手術を行った。卵巣茎捻転 の多くは、器質的疾患をともなっていることが多 く、悪性のことを考虑すると温存することが躊躇 されるが、女児や若年女性においては正常卵巣の 茎捻転や卵巣広汎性浮腫の茎捻転が多いことから 捻転解除の重要度が増すと考える。

\section{結 語}

発症から 12 時間後の緊急の腹腔鏡下手術で傍卵 巣囊腫茎捻転、広汎性卵巣浮腫、卵巣線維腫を同 時に確認した。超音波所見でネックレスサインを 有する充実性腫瘍像であること、卵巣周囲に傍卵 巣囊腫や線維腫を伴うこと、17才で無月経である ことなどの臨床的特徴から広汎性卵巣浮腫を強く 疑い、卵巣を温存できた。術後に卵巣浮腫の改善 と多囊胞性卵巣を確認した。広汎性卵巣浮腫の発 生機序として還流障害説と器質説の両説で説明し うる状態が考えられた。広沉性卵巣浮腫の臨床的 特徵を周知することは無用な卵巣摘出を回避する など臨床判断上で重要と思われる。

*本論文の要旨は第114回近畿産科婦人科学会にお いて発表した。

\section{文献}

1 ) 永野玲子、他：術前診断が困難であった卵巣 massive edema の 1 例、日産婦東京誌、49(3): 376, 2000

2 ) 杉本修、他：本邦婦人における多囊胞性卵巣症候群の 診断基準設定に関する小委員会（平成 2 年度から平成 4 年度）検討結果報告、日産婦誌、45: 1359, 1994
3) Kalstone CE, et al: Massive edema of ovary stimulating fibroma, Obstet \& Gynecol, 34: 564, 1969

4 ) Bychkow V, et al: Massive ovarian edema. Four cases and pathogenetic considerations, Acta Obstet Gynecol Scand, 66: 397, 1987

5 ）森村豊、他：卵巣広汎性浮腫の 1 例、産と婦、8(117): 1189, 1995

6 ) Umesaki N, et al: Successful preoperative diagnosis of massive ovarian edema aided by comparative imaging study using magnetic resonance and ultrasound, Eur J obstet Gynecol Reprod Biol, 89: 97, 2000

7 ) Tevfik G,et al: Unilateral massive ovarian edema and polycystic ovaries A case report.Obstet \& Gynecol, 97: 258, 2001.

8 ）西田敬、他：卵巣腫瘍の茥捻転に関する臨床的および 組織学的検討、産婦人科の実際、30(9): 1463, 1981

9 ) Templeman BC, et al: The Clinical Course of Unresected Ovarian Torsion,J Pediatric Surgery, 35(9): 1385,2000

10) Pansky M, et al: Conservative Managemant of Adnexal Torsion in Premenarchal Girls,J Am Asso Gynecol laparo, 7(1): 121, 2000 